\title{
2: 15682368-15721823
}

National Cancer Institute

\section{Source}

National Cancer Institute. 2: 15682368-15721823. NCI Thesaurus. Code C42122.

Physical location of DDX1_Gene 